\title{
The Effect of Food Preservatives on pH Homeostasis in Escherichia coli
}

\author{
By CHRISTINE V. SALMOND, ROHAN G. KROLL AND IAN R. BOOTH* \\ Department of Microbiology, Marischal College, University of Aberdeen. \\ Aberdeen $A B 9$ IAS, UK
}

(Received 28 March 1984; revised 25 June 1984)

\begin{abstract}
The effects of cinnamic, propionic, benzoic and sorbic acids on the growth and intracellular $\mathrm{pH}$ of Escherichia coli were investigated. The data suggest that the potency of weak acids as food preservatives is related to their capacity to reduce specifically the intracellular $\mathrm{pH}$. The data also suggest that although both the undissociated and dissociated forms of the acid cause the intracellular $\mathrm{pH}$ to fall, growth inhibition is due predominantly to the undissociated acid.
\end{abstract}

\section{INTRODUCTION}

It is generally recognized that bacteria maintain their cytoplasmic $\mathrm{pH}\left(\mathrm{pH}_{\mathrm{i}}\right)$ relatively constant despite variations in the environmental $\mathrm{pH}$. The mechanisms by which this homeostasis is achieved are poorly understood, although controlled, cation-dependent proton flux appears to be central (Padan et al., 1982; Booth \& Kroll, 1983). The requirement for homeostasis has been demonstrated unequivocally in Streptococcus faecalis (Harold \& van Brunt, 1977). Gramicidin-treated cells incubated in an enriched growth medium demonstrated a marked growth inhibition as the incubation $\mathrm{pH}\left(\mathrm{pH}_{\mathrm{o}}\right)$ was lowered. Inhibition was complete at $\mathrm{pH}_{\mathrm{o}} 6.0$ (Harold \& van Brunt, 1977). Similar data are not available for respiring organisms in which the capacity to regulate cytoplasmic pH is somewhat greater (Booth \& Kroll, 1983).

The constancy of cytoplasmic $\mathrm{pH}$ in growing cells leads to the presence of a progressively larger transmembrane $\mathrm{pH}$ gradient $(\Delta \mathrm{pH})$ as $\mathrm{pH}_{\mathrm{o}}$ is lowered (Kashket, 1981 ; Ahmed \& Booth, 1983). In consequence it is not surprising that growth inhibition by weak acids should be more potent at low $\mathrm{pH}$. The weak acid traverses the membrane in its undissociated form and dissociates in accordance with the intracellular $\mathrm{pH}$, liberating a proton in the cytoplasm. When $\Delta \mathrm{pH}$ is large, the amount of acid dissociating in the cytoplasm is correspondingly larger. Consequently, the potential effect of the weak acid accumulation on intracellular $\mathrm{pH}$ increases as $\mathrm{pH}_{\mathrm{o}}$ is lowered. In such a model, $\mathrm{H}^{+}$is viewed as the inhibitor. However, it has long been held that with weak acid food preservatives the undissociated acid is the inhibitor (Bosund, 1962). Recently, in reviewing the effects of sorbic acid on bacterial cells Eklund (1983) proposed that the undissociated acid was some 10-600 times more effective as an inhibitor than the dissociated acid.

Previously, as a result of studies on membrane vesicles, the antimicrobial activity of food preservatives had been attributed to inhibition of transport by reducing the $\Delta \mathrm{pH}$ component of the protonmotive force (Freese et al., 1973). However, Eklund (1980) concluded that while this was correct for the parabens it could not explain the inhibition by weak acids. We have investigated the effects of four weak acid food preservatives on growth and intracellular $\mathrm{pH}$ of Escherichia coli to determine the relationship between $\mathrm{pH}_{\mathrm{i}}$ and growth inhibition. The data suggest that the weak acids which are potent inhibitors of growth have a greater effect on intracellular $\mathrm{pH}$ than other weak acids of similar $\mathrm{pK}$. There was a significant correlation between

\footnotetext{
Abbreviations: $\mathrm{pH}_{1}$, intracellular $\mathrm{pH} ; \mathrm{pH}_{0}$, extracellular $\mathrm{pH} ; \mathbf{H A}$, undissociated acid; $\mathrm{A}_{\mathrm{i}}^{-}$, intracellular anion; $A_{0}^{-}$, extracellular anion.
} 
intracellular $\mathrm{pH}$ and growth inhibition. The data point to the involvement of the undissociated acid in inhibition of $\mathbf{p H}$, maintenance.

\section{METHODS}

Chemicals. All chemicals were purchased from BDH (Analar grade) except benzoic acid, acetylsalicylic acid. propionic acid, sorbic acid and Triton X-100, which were from Sigma. PPO was from Packard Instruments: POPOP was from Koch-Light: trans-cinnamic acid was from Aldrich. Radiochemicals were from Amersham. except $[7.14 \mathrm{C}]$ benzoic acid, which was from New England Nuclear.

Bacterial strain and growth conditions. Escherichia coli strain 7 (Hayashi et al., 1964) was kindly supplied by Dr B. P. Rosen, University of Maryland School of Medicine, Baltimore, Md., USA. Cell suspensions were grown aerobically at $30^{\circ} \mathrm{C}$ overnight in $250 \mathrm{ml}$ flasks containing $100 \mathrm{ml}$ minimal medium which contained per litre: $\mathrm{NaH}_{2} \mathrm{PO}_{4} .2 \mathrm{H}_{2} \mathrm{O}, 5.3 \mathrm{~g}: \mathrm{K}_{2} \mathrm{HPO}_{4}, 11.15 \mathrm{~g}:\left(\mathrm{NH}_{4}\right)_{2} \mathrm{SO}_{4}, 2.64 \mathrm{~g} ; \mathrm{MgSO}_{4}, 74 \mathrm{mg} ; \mathrm{FeSO}_{4}, 278 \mu \mathrm{g}: \mathrm{CaCl}_{2}, 1.47 \mu \mathrm{g}$ : $\mathrm{ZnSO}_{+}, 161 \mu \mathrm{g}$ : glucose, $2 \mathrm{~g}$; adjusted to $\mathrm{pH} 7.0$. The last five ingredients were autoclaved separately in concentrated form and added when the medium had cooled.

Effect of weak acids on bacterial growth. The $\mathrm{pH}$ range of the growth media was adjusted by making up medium without the phosphate compounds but containing either $0.1 \mathrm{M}$-citric acid or $0.2 \mathrm{M}-\mathrm{K}_{2} \mathrm{HPO}_{4}$. The two solutions were mixed to give the desired $\mathrm{pH}$ and $\mathrm{KCl}$ was added as required, to make the $\mathrm{K}^{*}$ concentration constant at $190 \mathrm{~mm}$. The overnight cell suspensions were diluted into this medium at the required $\mathrm{pH}$ to give an $O \mathrm{D}_{\mathrm{bs}}$ of approx. 0.1, using a Pye Unicam SP600 spectrophotometer. Cultures were incubated aerobically at $30^{\circ} \mathrm{C}$ in a shaking water bath and the $\mathrm{OD}_{\mathrm{bs0}}$ of the culture determined. When $\mathrm{OD}_{\mathrm{bs}}$ had reached approx. $0 \cdot 2$, weak acids were added and growth was followed for a further $4 \mathrm{~h}$. Weak acids were dissolved in DMSO, which in control experiments did not interfere with growth at the concentrations used.

Measurement of rates of glucose consumption. Overnight cell suspensions were washed twice by centrifugation at $16000 \mathrm{~g}$ for $5 \mathrm{~min}$ and resuspended in minimal medium. Cell suspensions were then diluted into growth media and incubated as described above after addition of $4 \mathrm{~mm}$-glucose. At intervals, two $1 \mathrm{ml} \mathrm{samples} \mathrm{of} \mathrm{culture} \mathrm{were}$ transferred to plastic Eppendorf tubes ( $1.6 \mathrm{ml}$ capacity) and centrifuged for $20 \mathrm{~s} \mathrm{at} 12000 \mathrm{~g}$ in a microcentrifuge. A sample $(200 \mu \mathrm{l}$ ) was removed and incubated with $1 \mathrm{ml}$ of assay reagents (Sigma glucose oxidase kit) for $45 \mathrm{~min}$ at room temperature. The $A_{*}$ so of the samples and a calibration series treated identically was read and thus the extracellular glucose concentration determined.

Respiration studies. The rate of oxygen consumption by cell suspensions prepared as above was measured using a Clark $\mathrm{O}_{2}$ electrode, as described previously (Booth et al., 1979).

Measurement of intracellular $\mathrm{pH}$. The $\mathrm{pH}$, of growing and non-growing cell suspensions was measured by determination of the distribution of radiolabelled weak acids (Booth et al., 1979). Cell suspensions were incubated (with weak acid preservative when desired) at $30^{\circ} \mathrm{C}$ in stirred glass vessels to ensure continuous aeration. The weak acids $\left[2-^{-1+} \mathrm{C} \mid\right.$ dimethyloxazolidinedione $\left(10 \mu \mathrm{M}\right.$ final concn : sp. act. $\left.14.3 \mathrm{Ci} \mathrm{mol}^{-1}: 529 \mathrm{GBq} \mathrm{mol}{ }^{-1}\right)$ or, more usually, $\left[7.1^{4} \mathrm{C}\right]$ benzoic acid ( $2 \mu \mathrm{M}$ final conen : sp. act. $\left.24.4 \mathrm{Ci} \mathrm{mol}^{-1}: 903 \mathrm{GBq} \mathrm{mol}{ }^{-1}\right)$ were added together with ${ }^{3} \mathrm{H}_{2} \mathrm{O}$ (approx. I $\mu \mathrm{Ci} \mathrm{ml}^{-1} \mathrm{final}$ concn) as a total water marker. Al intervals, two $\mathrm{l} \mathrm{ml}$ samples were centrifuged in Eppendorf tubes for $20 \mathrm{~s}$, as described above. A portion ( $100 \mu \mathrm{l})$ of the supernatant was removed and transferred to a centrifuge tube containing a similarly treated cell pellet that had not been incubated with radiochemicals. This procedure ensured that the degree of quenching in the supernatant and pellet samples was equivalent. This enabled calculation of trapped and intracellular ${ }^{14} \mathrm{C}$ label in the experimental pellet (Booth et al. 1979). The remaining supernatant was aspirated with a vacuum line. All pellets were resuspended in minimal medium to $300 \mu \mathrm{l}$ final volume. A portion $(200 \mu \mathrm{l})$ was added to $2 \mathrm{ml}$ of scintillation fluid (Triton X-100, $333 \mathrm{ml}$; toluene. $666 \mathrm{ml} ;$ PPO, $4 \mathrm{~g}$; POPOP, $100 \mathrm{mg}$ ). The samples of supernatant and pellet were counted for radioactivity using a Packard TriCarb $300 \mathrm{C}$ scintillation counter with the following window settings: ${ }^{3} \mathrm{H}, 0-12 \mathrm{keV} ;{ }^{1+} \mathrm{C}, 12-156 \mathrm{keV}$. The spillover of ${ }^{14} \mathrm{C}$ into the ${ }^{3} \mathrm{H}$ channel was estimated by using identically prepared samples which had been incubated with ${ }^{+}+\mathrm{C}$ only. From a knowledge of $\mathrm{pH}_{0}, \mathrm{pH}_{1}$ was calculated (Booth et al., 1979).

Although benzoate is itself a food preservative it did not reduce $\mathrm{pH}_{\text {i }}$ when used in the concentration range $2-100 \mu \mathrm{x}$ at $\mathrm{pH}_{\mathrm{o}} 5$.

\section{RESULTS AND DISCUSSION}

\section{Growth inhibition by food preservatives}

The concentration dependence of the growth inhibition produced by benzoate, cinnamate, propionate and sorbate was investigated at $\mathrm{pH}_{\mathrm{o}} 5 \cdot 0$. Exponentially growing cultures of $E$. coli exposed to these weak acids exhibited inhibition which was dependent both on the identity of the weak acid (Fig. I) and on its concentration (data not shown). Of the four acids, cinnamate was the most potent inhibitor and propionate the weakest. Thus despite their similar pK values 


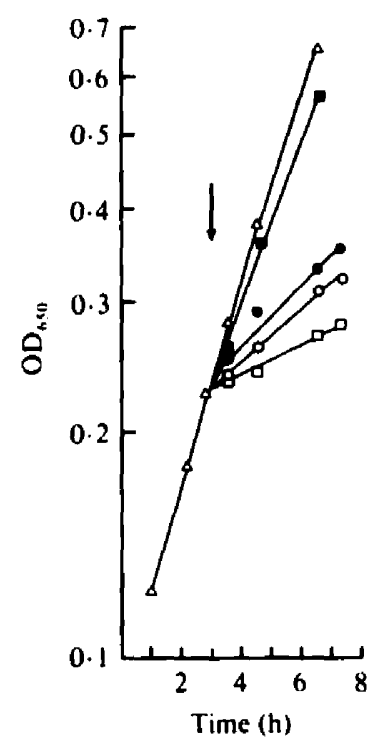

Fig. 1

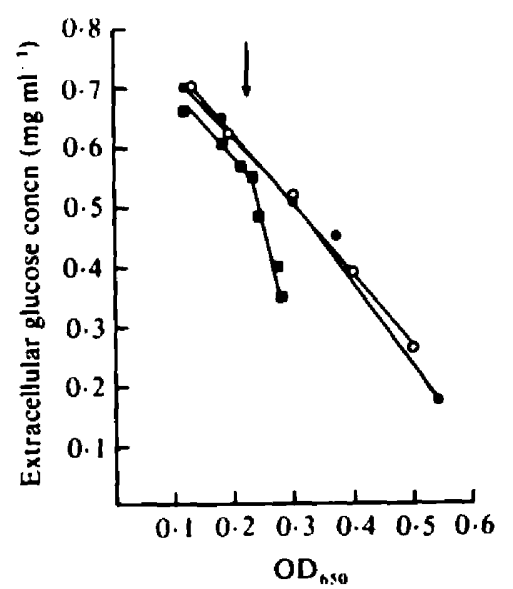

Fig. 2

Fig. 1. Inhibition of growth of $E$. coli at $\mathrm{pH}_{\mathrm{o}} 5.0$ by addition (arrow) of $0.5 \mathrm{~mm}$ propionic ( $\square$ ), benzoic $(O)$, sorbic $(O)$ and cinnamic $(\square)$ acids.

Fig. 2. Effect of addition (arrow) of $0.1 \mathrm{~mm}(O)$ and $0.5 \mathrm{~mm}$ ( $\square$ ) cinnamic acid on the consumption of glucose by $E$. coli at $\mathrm{pH}_{\mathrm{o}} \mathbf{5 \cdot 0}$. O. Control.

the acids were differentially effective as growth inhibitors. This suggests that the acids did not exert their effects on growth simply as a function of their excessive accumulation causing acidification of the cytoplasm. If this were the case the pattern of inhibition would reflect the pK values of the acids. In support of this suggestion, it was observed that the predicted intracellular concentration of the dissociated weak acids did not correlate with either the pK or the severity of growth inhibition (data not shown).

At higher values of $\mathrm{pH}_{\mathrm{o}}$ the same pattern of inhibition emerged, although higher concentrations of the acids were necessary to cause complete inhibition (data not shown).

During growth inhibition, glucose consumption continued, although its utilization was uncoupled from growth (Fig. 2). Thus during exponential growth an approximately linear relationship was observed between the residual glucose in the culture and the cell density. This relationship held in the presence of low concentrations of the food preservative cinnamate when growth inhibition was slight (Fig. 2). However, at higher concentrations (0.5-2 mM) of cinnamate, glucose consumption continued, while growth was severely inhibited (Fig. 2).

Similar data were obtained for all four acids. It is apparent that unlike the situation in Saccharomyces cerevisiae (Krebs et al., 1983), in E. coli glucose uptake is not the primary site of action of the food preservatives.

\section{Effects of food preservatives on $p H_{1}$}

All weak acids which are freely permeable across the cytoplasmic membrane will reduce $\mathrm{pH}_{\mathrm{i}}$ in a concentration-dependent manner. In the absence of direct effects on metabolism the potency of any weak acid at a given external pH value will depend on the $\mathrm{pK}$ of the acid. Acids of a low pK are generally more effective at collapsing the $\mathrm{pH}$ gradient than those of higher $\mathrm{pK}$. Thus for comparison of the effects of the acids on $\mathrm{pH}_{\mathrm{i}}$ it is necessary to normalize the data by reference to the concentration of the anion in the incubation medium. Cells of $E$. coli in the exponential phase of growth were incubated with the four food preservatives at a range of concentrations and also with the weak acids acetate and acetylsalicylate, and the internal $\mathrm{pH}$ was 


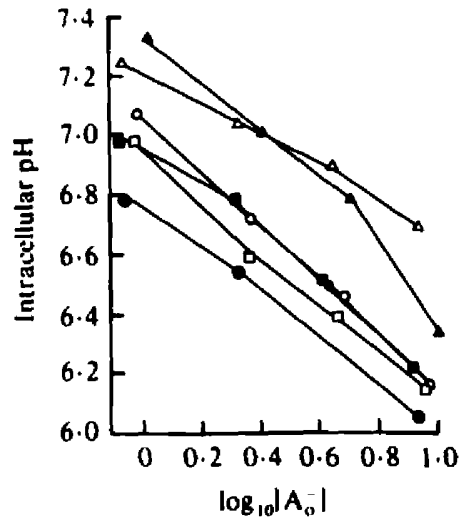

Fig. 3

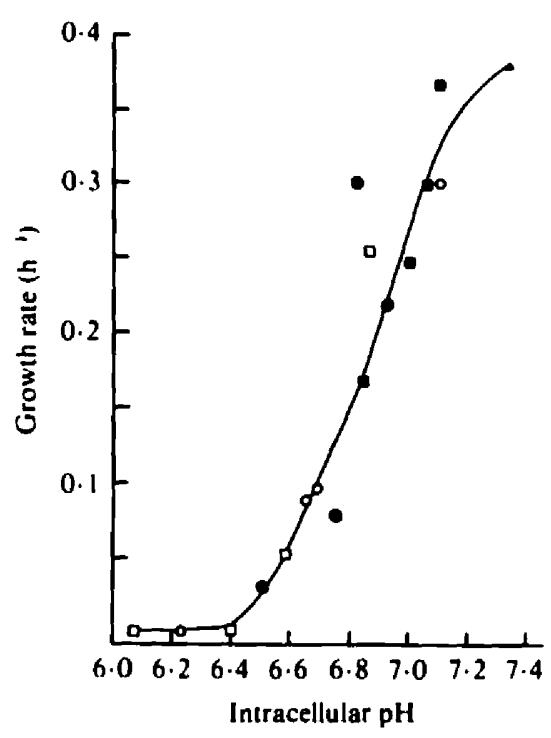

Fig. 4

Fig. 3. Effect of weak acids on $\mathrm{pH}_{4}$ of cultures of $E$. coli growing at $\mathrm{pH}_{0} 5 \cdot 5$. $A$, Acetylsalicylic $\left(\mathrm{pK}_{2} 3 \cdot 5\right)$; $\triangle$, acetic (pK, 4.7); $\square$, propionic; $O$. sorbic; $O$, benzoic; $\square$, cinnamic.

Fig. 4. Relationship between growth rate and $\mathrm{pH}_{1}$ of $E$. coli at $\mathrm{pH}_{\mathrm{o}} 5 \cdot 0$. Cinnamic ( $\square$ ), propionic ( $\square$ ), benzoic $(O)$ and sorbic $(O)$ acids were added to final concentrations of $0 \cdot 1,0.5,1.0$ and $2.0 \mathrm{mM}$. $\triangle$, Control.

determined. Acetylsalicylate and acetate had identical effects on the internal pH (Fig. 3). At an external anion concentration of $1 \mathrm{mM}$ the acids reduced $\mathrm{pH}_{\mathrm{i}}$ by 0.38 units at $\mathrm{pH}_{\mathrm{o}} 5.5$. All the food preservatives reduced the internal $\mathrm{pH}$ by a greater extent than either acetate or acetylsalicylate (Fig. 3). At an external anion concentration of $1 \mathrm{mM}$ the drop in $\mathrm{pH}_{\mathrm{i}}$ was $0.53,0.65,0.8$, and 0.84 for benzoate, propionate, cinnamate and sorbate, respectively. Thus when the acids were compared with each other on equal terms a different pattern of potency was observed from that seen when studying growth at a single $\mathrm{pH}$ value (Fig. 1). The fall in intracellular $\mathrm{pH}$ was complete within $20 \mathrm{~s}$ and no further significant change in $\mathrm{pH}_{\mathrm{i}}$ was detected with prolonged incubation.

In view of the action of the food preservatives on the intracellular $\mathrm{pH}$, a correlation was made between the degree of growth inhibition and $\mathrm{pH}_{\mathrm{i}}$ (Fig. 4). Despite the apparent differences in their effectiveness as growth inhibitors, all the four acids fitted the same relationship between $\mathrm{pH}_{\mathrm{i}}$ and growth. Thus at $\mathrm{pH}_{\mathrm{o}} 5$ growth was not inhibited until $\mathrm{pH}_{\mathrm{i}}$ fell below $\mathrm{pH}_{\mathrm{i}} 7 \cdot 1$, but became severe once $\mathrm{pH}_{\mathrm{i}}$ was reduced below $\mathrm{pH}_{\mathrm{i}} 6.8$ (Fig. 4). It thus appears that food preservative weak acids may all inhibit the capacity to maintain cytoplasmic $\mathrm{pH}$ above $\mathrm{pH}_{\mathrm{i}} \mathbf{7 \cdot 1}$.

\section{Is inhibition due to undissociated or dissociated acid?}

Using benzoate we investigated the efficacy of benzoate anion and benzoic acid as inhibitors by (a) varying the undissociated acid concentration at constant $\mathrm{pH}$ and $(b)$ varying the undissociated acid concentration by changing $\mathrm{pH}_{\mathrm{o}}$ at a constant total acid concentration. $A$ low total acid concentration $(2.5 \mathrm{~mm})$ was chosen to minimize the effects of dissociated acid on $\mathrm{pH}_{\mathrm{i}}$. Growth inhibition correlated strongly with the concentration of the undissociated acid regardless of the method of varying this parameter (Fig. $5 a$ ) The correlation between $\mathrm{pH}_{\mathrm{i}}$ and growth inhibition was again evident despite the two different methods of varying the concentration of the undissociated acid (Fig. $5 b$ ). 

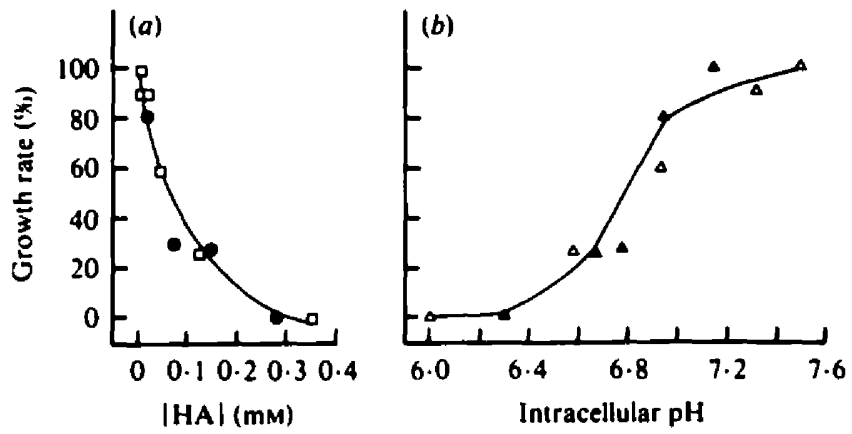

Fig. 5. (a) Effect of varying the concentration of undissociated benzoic acid on the growth rate of $E$. coli by varying $\mathrm{pH}_{0}(\square)$ or by varying the concentration of total acid at constant $\mathrm{pH}_{0} 5 \cdot 0$ (O). (b)

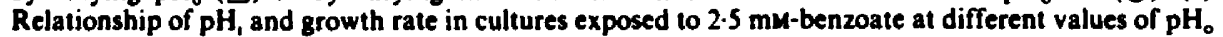
$\left(\mathrm{pH}_{0} 5 \cdot 0-7.0 ; \Delta\right)$ or to different concentrations of benzoate at $\mathrm{pH}_{0} 5.0(\Delta)$. Values corresponding to $100 \%$ growth rate were, typically, $0.28 \mathrm{~h}^{-1}$ at $\mathrm{pH}_{0} 5 ; 0.31 \mathrm{~h}^{-1}$ at $\mathrm{pH}_{\mathrm{o}} 5 \cdot 5 ; 0.33 \mathrm{~h}^{-1}$ from $\mathrm{pH}_{0} 6$ to 7.5 .

\section{Model for growth inhibition}

On the basis of the above data we propose that growth inhibition consists of two components. Specific inhibition of an unidentified metabolic function by the undissociated acid (HA), and a generalized inhibition caused by acidification of the cytoplasm. It is clear that although the latter is a significant cause of inhibition, the former specific effect is the more potent. Thus cells of $E$. coli can tolerate quite large changes in cytoplasmic $\mathrm{pH}$, down to $\mathrm{pH}_{i} 6.8$, without significant growth inhibition (Figs 4 and $5 a$ ). Below $\mathrm{pH}_{\mathrm{i}} 6 \cdot 8$, growth inhibition becomes severe but this arises in all cases from an increase in both $\mathrm{HA}$ and $\mathrm{A}_{0}^{-}$, i.e. an increase in both specific and non-specific inhibition. Thus at this point the data cannot be simply interpreted in terms of the effect of the acids on $\mathrm{pH}_{\mathrm{i}}$. Clearly it is significant that $\mathrm{pH}_{\mathrm{i}}$ is lowered to a greater extent by food preservatives than by weak acids of a similar pK (Fig. 3). This suggests that the inhibitory action of $\mathrm{HA}$ has a synergistic effect with accumulation of the acid (as $\mathrm{A}^{-}$) on $\mathrm{pH}_{\mathrm{i}}$. However, growth inhibition correlates most strongly with the concentration of HA (Fig. $5 b$ ). Thus the decline of $\mathrm{pH}_{\mathrm{i}}$ is unlikely to be the primary cause of growth inhibition.

We wish to thank SERC and Unilever Research for support for Christine V. Salmond and the University of Aberdeen for support to Rohan G. Kroll. Christine V. Salmond was in receipt of a CASE award. We wish to thank Professor Graham Gould for his advice and encouragement through this work. We also wish to thank Dr B. M. Mackey, and Dr E. P. Bakker for helpful comments and unpublished data.

\section{REFERENCES}

AFMED, S. B BOOTH, I. R. (1983). The effect of $\beta$ galactosides on the protonmotive force and growth of Escherichia coli. Journal of General Microbiology 129, 2521-2529.

Booth, I. R. \& Krolt, R. G. (1983). Regulation of cytopjasmic $\mathbf{p H}\left(\mathrm{pH}_{1}\right)$ in bacteria and its relationship to metabolism. Transactions of the Biochemical Society 11, 70-72.

Booth, I. R., Mitchell, W. J. \& Hamilton, W. A. (1979). Quantitative analysis of proton linked transport systems: the lactose permease of Escherichia coli. Biachemical Journal 182, 687-696.

Bosund, I. (1962). The action of benzoic and salicylic acids on the metabolism of microorganisms. Adeances in Food Research 11, 331-353.
EkLUND, T. (1980). Inhibition of growth and uptake processes in bacteria by some chemical food preservatives. Journal of Applied Bacteriology 48, 423432.

EKLUND, T. (1983). The antimicrobial effect of dissociated and undissociated sorbic acid at different pH levels. Journal of Applied Bacteriology 54, 383389.

Freese, E., Sheu, C. W. \& Galliers, E. (1973). Function of lipophilic acids as antimicrobial food additives. Nature, London 241, 321-325.

HAROLD, F. M. \& VAN BRUNT, J. (1977). Circulation of $\mathrm{H}^{+}$and $\mathrm{K}^{+}$across the plasmamembrane is not obligatory for bacterial growth. Science 197, 372373. 
Hayashi. S. KOCh. J. P. \& Lin, E. C. C. (1964). Active transport of $\mathrm{t}-\alpha$-glycerophosphate in Escherichia coli. Journal of Biological Chemisiry 239. 3098 -3105

KASHKET. E. R. (198I). Effects of aerobiosis and nitrogen source on the protonmotive force in growing Escherichia coli and Klebsiella pneumoniae cells. Journal of Bacteriology 146. 377-384.
Krebs, H. A., Wiggins, D., Stubas, M., Sols. A. \& BEDOYA, F. (1983). Studies on the mechanism of the antifungal action of benzoate. Biochemical Journal 214, 657663 .

Padan. E., Zilberstein. D. \& Schuldiner, S. (1982). pH homeostasis in bacteria. Biochimica el biophysica acta 650, 151 - 166 